\title{
Study on the Financing Mode of Railway based on PPP
}

\author{
Zhejuan Fan \\ Beijing Jiaotong University, China \\ 14120503@bjtu.edu.cn
}

Keywords: PPP; railway; financing model.

Abstract. Transportation plays an important role in promoting the economic development of a country. As the main mode of transportation, the railway transportation system needs to adapt to the level of economic development. For our country, the railway is the backbone of the transportation system, and it is very important to the economy. But in face of the rapid development of China's economy, the railway construction is faced with the shortage of funds, the railway construction is difficult to meet the needs of economic development. In order to solve the problem of lack of funds for railway construction, China has constantly tried new financing ways to reform the railway investment and financing system. As a new financing model, PPP model has achieved good results in some foreign and domestic infrastructure construction.

\section{Introduction}

By the end of 2014, China railway operating mileage has reached 11.18 million kilometers, by the end of 2013 railway operating mileage has reached 10.31 million kilometers, of which the line speed of 120 kilometers per hour and above over 4, 000 kilometers, the line speed of 160 kilometers more than 2 million km, high-speed railway exceeded 1 million $\mathrm{km}$, the construction scale of 1.2 million kilometers, making the high speed railway which has been completed and are under construction become the longest in the word.

Due to large positive externalities and strong asset specificity of railway, the railway construction of huge financial pressure must be resolved by the government itself. In order to solve the problem of financing of public utilities, the Chinese government issued a series of regulations to introduce private capital. PPP model refers to the government and social capital cooperation model, it introduces private capital into the field of infrastructure and public services. PPP financing mode can reduce the financial pressure on the government, making the public get the effective supply of higher quality public works and public service, on the other hand it will create market space for private capital.

\section{Literature review}

There is a lot of research on the PPP mode of domestic and foreign scholars, they think influence factors may conclude the type of PPP financing, allocation of control rights, risk sharing and other aspects of the application of PPP model, but because of the special character of railway, our country does not use PPP financing model in railway construction in large scale.

The summary of articles since 1999 to 2013 on PPP financing mode, Robert Osei Kye and Albert P.C. Chan pointed out that the essence of PPP model is a value of money purchasing, which combines competitive bidding, flexible negotiation and risk sharing between participants. The key factors of the success of PPP financing is the allocation and sharing of risk, powerful private consortium, policy support, social/public support and transparent procurement [1]. José M. Viegas found there are two important factors affect PPP project in traffic field: one is to ensure retention PPP project cycle technology, consumer preferences to stable, second is government policy in terms of price, equity principle and the changes of access rules [2]. Elisabetta Iossa and David Martimort thinks that the moral risk, private information of external shocks, the threat of corruption is internal factors of contracts incomplete. While higher uncertainty contributes to higher possibility that the contractors want to avoid risk. The higher the cost of corruption, the higher incomplete degree of contract is [3]. 
S. Thomas Ng et al. considered PPP project is to make the public sector, the private consortium and the society as a whole to realize a win-win project, they test the validity of key factors of PPP by survey of industries in Hong Kong. The study found the cost efficiency and financial attractiveness are important to public sector and private consortia. Long-term of project, private consortia and government policy project are also important factor in the success of PPP, while the initial stage of feasibility evaluation are essential success factors [4].

\section{Cause analysis}

Nature of the industry. The construction of railway needs huge investment in fixed assets, and the network construction cycle is long, in the short term capital cannot recover quickly. But the marginal cost of the products production is very low, leading to the long-term average cost curve at high output levels is still down, thus the railway belongs to the natural monopoly industries. Because of lack of competition, the railway needs the government to control the price.

Sunk cost. The construction of the railway investment in fixed assets has strong asset specificity, so they are always considered as sunk costs, which can't take back after construction. Private enterprises always make a cost-benefit analysis before they invest. Private enterprises’ earning is:

$$
P V D=\sum_{t=1}^{n} \frac{I(n)}{(1+r)^{n}}
$$

\section{PVD=Discounted value of enterprise all income}

$\mathrm{I}(\mathrm{n})=$ The enterprise earns in Nth year

If the enterprise finds the future income's present value is not enough to make up for the cost, namely: $P V D \leq T C$, the enterprise cannot get their expected investment returns and will not to invest. At present, our country controls railway ticket, enterprise investment profits are not enough to attract the private enterprise to invest. On the other hand, railway investment has uncertainty, enterprise is difficult to accurately to evaluate earnings, so it also reduces the private-sector investment in railway. Positive externalities. Traffic is one of the important factors to promote the development of economy, and it directly influences the convenient degree of a region. Convenient transportation can make regions develop rapidly, help to local employment. Railways have strong positive externalities, however even if corporate investment in railway construction, positive externalities are unable to obtain by the company, so railway is lack of incentives to attract private investment.

\section{PPP financing model analysis}

Advantages of PPP financing model. Private capital through the PPP model invests in the construction of public goods, solving the shortage of financial funds. At the same time private capital is project participant in PPP model, thus the funds invested doesn't require debt service, which won't bring the government debt risk. PPP financing mode promotes investment diversification, using market means to raise funds, breaking the monopoly of the government in the construction of infrastructure, so that private capital can get profit, and improve the quality of the supply of public goods or services, increase the total social welfare.

PPP financing model feasibility analysis. With China's sustained and rapid economic development, the non-governmental investment of our country on the total amount and growth rate showed a rapid growth momentum but there are not enough projects which have large attraction to private capital. The railway project can guarantee a stable income, so it is attractive enough to attract capital. At the same time PPP model contract ensure that the private sector has the incentive and restraint mechanism. The participating private sector has higher technical means and more efficient management methods than the market average level. More important, the final control of the railway 
is still retained in the hands of the government, which conducive to the long-term stability of railway products, which ensure that the railway to play the basic industrial functions, and promote the development of the national economy.

\section{Model construction}

In this paper, the dynamic game method is used to study the impact of PPP project risk on the PPP project success. The private enterprise and the government are actors, they choose a course of action in the different strategic space. This paper will analyze how different conditions will impact choose of two participators. In the first case, the assumption is that the cash flow is high and low, private enterprises make investment decision. The second case, by using principal-agent model, we will analyze how to effectively reduce the possibility of credit risk under credit risks.

Market demand. The market is instable, so they maybe face high demand or low. Assumptions is that high future market demand with probability p, 1-p probability for the low demand, high demand for private sector profit for $\mathrm{H}$, low demand private sector profit is $\mathrm{L}$, the private sector production of public goods cost $\mathrm{C}$. If the private invests, private capital is expected to obtain the profit:

$$
\pi=p H+(1-p) L-C .
$$

Private capital will be invested only when the firm's expected profit is higher than zero. This situation may lead to public goods can't provide, resulting in a decline in the total social welfare. Therefore, the government can take subsidies for private capital, so that private capital at least can obtain the normal rate of return. If government subsidies $\mathrm{T}$, the private capital will get:

$$
\pi=p H+(1-p) L+T-C .
$$

Before bidding, government should investigate the need of market if they expect that private capital can't get benefit and may not supply public goods , the government should estimate subside which can promote private capital investment and provision of public goods.

Credit risk. Government department in the PPP model is client, and private enterprise is agent. Due to the principal the existence of information asymmetry, it is unable to accurately estimate the costs of production of public goods, but government can estimate cost $C_{0}$ by the past relevant project construction. The private sector expect $\mathrm{R}$ by provide public good, the market rate of return is $\mathrm{r}$. Setting up a private sector offer is $C$, the actual construction cost is $C_{1}$, the private sector will participate in the construction of the PPP project only when:

$$
\pi_{0}=R-C_{1} \geq r C_{1} .
$$

In order to reduce the likelihood of default in the private sector, government departments should require the private sector submitting bid, in order to reduce fund pressure of government who need to complete the construction when the private sector is breach the contract. If the private sector in accordance with the contract to complete construction projects, government departments to return the part of the deposit, deposit amount $\left(\mathrm{C}_{0}-\mathrm{C}\right)^{2}$. In this case, if the private sector defaults, then its expected profit into:

$$
\pi_{1}=R-C-\left(C_{0}-C\right)^{2} .
$$


If $C_{1} \leq\left(C_{0}-C\right)^{2}$, that is $\pi_{0} \geq \pi_{1}$, in order to ensure the maximization of profit, the private sector will not say less than the actual construction cost price to win the project construction qualification, this can reduce the private sector credit risk which lead to the possibility of failure of PPP projects in a certain extent.

\section{Conclusions and policy recommendations}

Establish a reasonable risk sharing mechanism. The risk of the project can't be undertaken by any single participant alone, so the risk should be dispersed effectively, the reasonable allocation of risk is the condition of the successful operation of the project financing. There is greater uncertainty and risk because of long construction period, long recovery period and high investment. Therefore, it is necessary to establish a reasonable mechanism for risk diversification, to raise the enthusiasm of private sectors to participate in the construction of railway.

Change supervision mechanism. The government function has been changed from main body to only providing products and services by PPP model. The regulation of railway PPP financing should focus on the two aspects of price and security, and should not be too much interference in the operation of the project.

The government should ensure that the private sector's profits, and make lower fares as much as possible, to ensure that the railway industry promoting effect on the economy, so government can take the price cap and price discrimination mechanisms. Safety supervision should cover construction and operation of the whole project process.

Give full play to the functions of government. Introducing PPP model in railway construction is an important step to introduce competition in the rail industry, the government should accurately locate their own functions. In this process, government should provide the necessary support and assistance. Government should do some change, their role should change from constructor to assistant of private sector, ensuring completing the project and supervising the project. Their responsibility is not only ensuring the private sector can get normal return, but also guaranteeing the public interests. They should be responsible for the overall organization and coordination of railway projects, and allocate right and responsibility of all participants reasonably.

\section{Acknowledgment}

At the point of finishing this paper, I'd like to express my sincere thanks to all those who have lent me hands in the course of my writing this paper. First of all, I'd like to take this opportunity to show my sincere gratitude to my tutor, professor Tan .Secondly, I’d like to express my gratitude to my family.

\section{References}

[1] Robert osei-kyei Albert-P.C.-Chan: Review of studies on the Critical Success Factors for Public-Private Partnership (PPP) projects from 1990 to 2013, international Journal of Project Management, vol. 33(2015), pp. 1335-1346.

[2] José M.viegas: Questioning the need for full amortization in PPP contracts for transport Infrastructure, Research in Transportation Economics, vol. 30(2010), pp. 139-144.

[3] Elisabetta iossa, David Martimort: Corruption in PPPs, Incentives and Contract Incompleteness, International Journal of Industrial Organization, (2015),pp. 1-42.

[4] S.thomas ng,Yoki M.W.Wong,James M.W.Wong: Factors influencing the success of PPP at feasibility stage e A tripartite comparison study in Hong Kong, Habitat International, vol. 36(2012), pp. 423-432. 